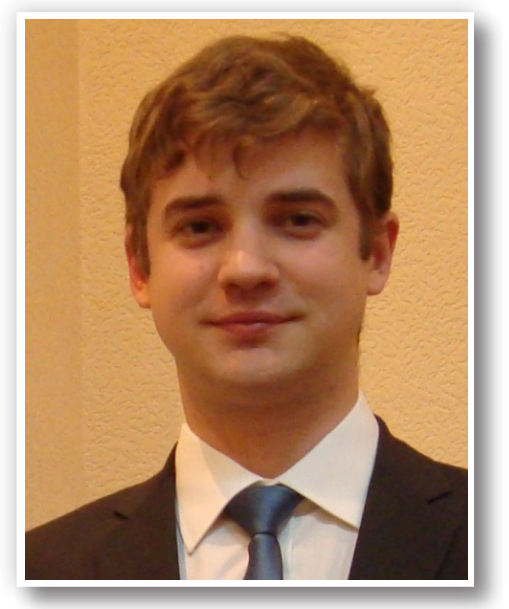

Fedir Podshyvailov,

Candidate of Psychological Sciences,

Senior Research Fellow of the of Giftedness

Development Projecting of Institute of

Gifted Child of NAES of Ukraine,

Kyiv

ORCID: https://orcid.org/ 0000-0002-0142-6172

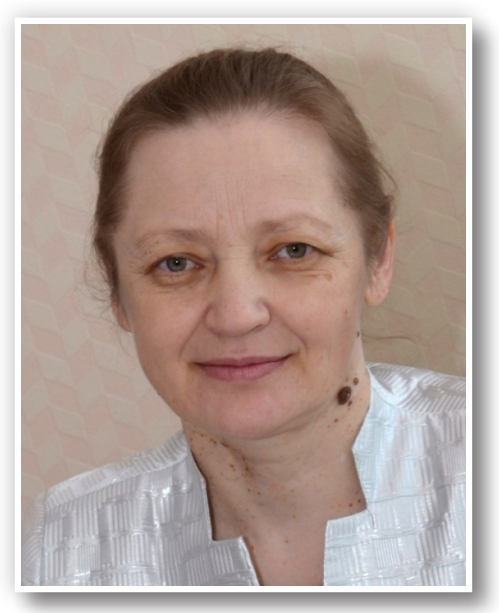

Lidiia Podshyvailova,

Candidate of Psychological Sciences,

Associate Professor in the Department of General,

Age and Pedagogical Psychology

of Borys Grinchenko Kyiv University,

Kyiv

ORCID: https://orcid.org/0000-0002-2902-3586

УДК 167.33

DOI: https://doi.org/10.32405/2309-3935-2019-2(73)-47-56

\title{
MOTIVATIONAL SPHERE OF MODERN PSYCHOLOGY STUDENTS: THEORETICAL-EMPIRICAL ANALYSIS OF THE RESEARCH IN UKRAINE
}

Summary.

The article presents the peculiarities of the psychology students' motivational sphere, revealed as an empirical study result, conducted on the basis of the personality's motivational sphere theoretically grounded model, which includes four components: orientation, mobilization, actualization and realization. The personality's motivational sphere is considered as the centre of the personality space, where all personality properties, determining the motivational processes' character, intersect; and which defines personality's orientation, provides its firmness, stability and integrity. Quantitative data processing was carried out by the means of the average values and percentage ratios defining, correlation and factor analysis. Empirical indicators for the study are emotional orientation; adaptability, personality anxiety, orderliness, perfectionism; academic motivation (scales «knowledge gaining», "profession mastering», "getting a diploma»); control localization, achievement motivation (striving for success, fear of failure), value orientations.

Key words: personality's motivational sphere; the model of personality's motivational sphere; the components and indicators of personality's motivational sphere; the features of psychology students'motivational sphere; empirical research.

The beginning of the XXI Century was marked by the tension increase in all human life spheres. The threat of unemployment, tough competition in the labour market, social processes' uncertainty and instability, globalization and virtualization in the total reformation and conflict growth conditions, a decline in the general culture level, lack of spirituality have led to a rapid growth of the need for qualified psychological help in a large number of people. All this, in turn, leads to an increase in the psychologist's professionalism and personality requirements, whose main mission is to improve the psychological culture of people, to promote the development of giftedness in the younger generation. Particularly actual becomes a problematics of a motivational sphere, which ensures personality integrity and individual uniqueness of a person.

The whole succession of psychological works on the psychology of motivation thorough analysis elicited great amount of modern theories and approaches to the understanding of motivation phenomenon, to analyze which within one paper is not possible.

Thus, the essence of each theory, each approach reflects in key notions, in which the researches define the main motivational phenomena, processes and states. In the work [2] the analysis of motivational phenomena through the defining of the psychology of motivation 
main notions basing on the axiomatic approach [1] was established. While constructing certain system applying the axiomatic approach, choose several statements, included to the system without proving, they are the axioms of the system. The rest of statements may be included to the system only when they are the consequence of the system's axiom. The notions, included in the system without definition, are initial notions; the rest of the system's notions have to be defined through the initial or defined earlier notions. Consistency is one of the most important conditions for the axiomatic model construction; because an inconsistent system is disposed from any cognitive value.

The basic notions characterizing motivational sphere are a need, requirement, inclination, desire, cognitive control (will, conation), motive and motivation. The initial notion concerning motivational sphere in our opinion is a «need». Need is an objective attribute of the organism as an open system, indicating the lack of something external and impels an organism to interact with the surrounding. The next, basic notions «requirement», «inclination», «desire», «cognitive control», «motive», «motivation» and «intention» were defined. The requirement, in its turn, is an objectified, specified in the psyche (but not in consciousness) need. With the filling of need with the affective energy, inclination arises, with the filling of requirement with the affective energy - desire. Motivation is a dynamic process of specification, awareness of a requirement, a desire arising, motive generation and formation of an intention to satisfy a requirement. At the same time, the entire motivational process may take a split second, and its separate components are not always actualized in details in a consciousness of a person. Motive - is a conscious requirement, attended with a desire of its satisfaction; intention - is a result of awareness and substantiation of an action plan, intended for the requirement satisfaction. Cognitive control - is a conscious process of an affective energy involvement (that is organism's physical energy, mediated by desires) for the fulfilment of actions, intended for an acknowledged requirement's satisfaction; cognitive control in some extent attends a motivational process, starting with desire formation.

In general motivational process is the following: need $\rightarrow$ requirement $\rightarrow$ motivation $\rightarrow$ motive $\rightarrow$ desire $\rightarrow$ activity. If the desire to act for the requirement satisfaction is initially absent, it is forming with the help of a cognitive control.

The requirement for motivational phenomena improvement and structurization resulted in the defining of a human personality's separate sphere - motivational. The personality's motivational sphere is considered as the centre of the personality space, where all coordinate axis (personality properties), determining the motivational processes' character, intersect [4].

Thus, the personality's motivational sphere is considered not as a system of motives, but as a centre of personality, where all its properties intersect. Any personality's the motivational process, the task of which is energy involvement for the fulfilment of activity, which personality performs during the life.

The analysis of references, describing different motivational phenomena researches, gave us an opportunity to define (besides initial and basic, presented above) the whole chain of notions, characterizing personality's motivational sphere: orienting reflex, orienting activity, bent, orientation, set, attitude, apperception, dynamical stereotype, interest, values, senses, value orientations, worldview, world picture and so on; and notions, indicating such personality properties, as locus of control, adaptiveness, orderliness, anxiety, perfectionism, and others, that determine motivational process, showing the basis of potential motivation.

These notions' systematization and structuring made it possible to construct and theoretically substantiate a personality's motivational sphere model [3]. In order to construct the personality's motivational sphere axiomatic model, necessary and sufficient criteria of the researching phenomenon theoretical analysis were defined. Considering, that human psyche is not static, but a dynamic phenomenon, which receives quantitative and qualitative changes, the criterion of ontogenetic consequence was defined. Motivational phenomena are displayed in consciousness to a different extent. In the personality's motivational sphere model construction, we proceeded from the psychodynamic theory statement about the unity and simultaneous opposition of the conscious and extramental in the human psyche. The extent of consciousness attraction to the motivational process that is the level of motivational phenomena consciousness is indicated in the level of awareness criterion (on the scale extramental - conscious). For the motivational phenomena analysis and structuring the criterion of inherency - acquiry and the criterion of functionality were distinguished.

Necessary for a certain model construction process of generalization and abstracting, is related with the process of categorization. Following the statements about the categorization and distinguished analysis criteria (ontogenetic consequence, level of awareness, inherency acquiry, functionality), we made an attempt to classify, systematise and generalise different notions, correlating with personality's motivational sphere, to structure motivational phenomena and to present them as a personality's motivational sphere model [2].

Four components of personality's motivational sphere were distinguished (orientation, mobilization, actualization and realization), which sequentially turn one into another, generating a four-stroke cycle.

In the human ontogenesis, these components are functioning according to dialectical laws of development, providing personality's motivational spheres' cyclic character.

Personality's motivational sphere model reflects a personality's motivational sphere structure, a stepwise algorithm of structural components' interaction and its algorithm's cyclicity as a feedback and reciprocal transition of structural components. 
The presented model - it is a structural stepwise algorithm of the personality's motivational sphere functioning.

The names of structural components according to the criterion of functionality indicate motivational sphere's provided function concerning a personality. Consequently, the personality's motivational sphere orientation component provides general and differential orientation of personality in the environment. Owing to it a general estimation of external conditions corresponding to the internal properties (such as, for instance, a need) of human organism and differentiation of an object and social surrounding features concerning the safety of dangerousness of the environment, is performed for the providing of internal balance and integrity of a person as a system. Contently orientation component is a system of inherent inclinations, premises, and certain reference points, providing a general and differential orientation in the environment. The form of a personality's motivational sphere orientation component demonstration, indicators are typological properties of a nervous system, individual features of analyzers' construction, cerebral cortex zones, drives, dispositions, orientation, emotional orientation etc. A motivational sphere's orientation component integrally provides an overall orientation of personality as an open system, permanently interacting with an environment.

The second component of a personality's motivational sphere reflects the function of personality's present forces and resources mobilization for the fulfilment of its interaction with an environment. Mobilization component contently is a system of vested, developed inclinations in a lifetime experience, reflecting in character properties, and individual style of activity. In a certain sense it is an instrumental providing of personality's activity. Dynamic stereotype, sets, attitudes, psychological complexes, psychological defences, accentuations, adaptiveness, personality anxiety, orderliness, perfectionism, individual style of activity etc. are the form of demonstration and, at the same time, the indicators of personality's motivational sphere mobilization component. A motivational sphere's mobilization component integrally provides personality's resistance in different demonstrations of its activity in the processes of its interactions with the surrounding world.

The third personality's motivational sphere component provides a function of a present human abilities (forces, resources) actualization and previously defines a necessary quantity of resources for the activity fulfilment. Consequently, it is named - actualization component of personality's motivational sphere. Contently it is a system of human potencies' transition into a real ability of realization through the mechanisms of awareness that directs personality on the development, on self-motivation. In a sense actualization component can be an academic motivation and reflects some kind of a zone of proximal human development, the space of developing of its life resource optimal spending ability, and, as far as possible, developing of it. The form of demonstration and, at the same time, the indicators of this component is interests, professional orientation, academic motivation, study mo- tives etc. Personality's motivational sphere actualization component integrally provides personality's stability in different demonstrations of its activity in the processes of interactions with the surrounding world.

The fourth component according to the functional criterion is personality's motivational sphere realization component, providing the realization, fulfilment of a man in the surrounding world. Contently this component is a system of values, senses, worldview positions, realizing a man as a personality and providing its stability in behaviour, deeds, activity. Consequently, the form of demonstration and, at the same time, its indicators is a locus of control, achievement motivation, values, senses, worldview, sense of life, world picture etc. Personality's motivational sphere realization component integrally provides integrity of personality as an open system in all its demonstrations towards the surrounding world and itself.

Each component is an appropriate tact of four-stroke cycle of personality's motivational sphere functioning. In each act of interaction of a man with a surrounding a motivational process starts with orientation component, which passes on the mobilization, which in its turn changes with actualization and finishes with realization component. In the model at the same time are presented the ontogenetic consequence of personality's motivational sphere unfolding, and movement from inherence to acquisition of motivational phenomena, that is supported by the motivational processes awareness level increasing: a man is born with some inner inclinations, need, orientation, which in the process of individual experience gaining progressively passes into the traits of a character, individuality, which, in their turn, start to define interests, worldview, and, finally, establishment of values, senses, world picture of a man, which, in their turn, on the new stage of human development start fulfilling the function of the personality's orientation in the environment.

The described theoretical positions became the basis for planning, organizing and conducting the personality's motivational sphere peculiarities' empirical study with the further quantitative analysis and qualitative interpretation of gained results.

The purpose of this article is to characterize the personality's motivational sphere peculiarities, revealed by the results of the psychology students' sample empirical study.

We consider the notion of 'peculiarity' as a characteristic, distinctive attribute. Peculiarities in psychology are a concrete, partial display, variation of the attribute as a more general concept. In particular, the one or another attribute's display level is often a psychological peculiarity. Distinguished at the stage of theoretical analysis four components of the student's personality's motivational sphere (orientation, mobilization, actualization and realization), have provided the structure of psychology students' personality motivational sphere peculiarities' empirical study.

The personality's motivational sphere model is theoretically substantiated on the basis of the axiomatic approach [1]. 
Considering that a comprehensive study of the personality's motivational sphere various displays is impossible within the limits of one empirical study, we defined separate indicators to characterize each component. These indicators, in our opinion, reflect the personality's motivational sphere's content characteristics and are sufficiently informative concerning the personality's motivational sphere peculiarities.

The orientation component indicators. The orientation component is represented by the emotional orientation indicator (V. Semichenko's technique for the structure of emotional orientation determining).

The mobilization component indicators. The mobilization component is represented by the adaptability (technique «The Adaptability Self-Assessment» - a modified version of the S. I. Boltivets' technique), and personality anxiety (Ch. Spielberger's Technique of Personality Anxiety's Level Determining in Yu. Khanin's adaptation), the orderliness (E. Komarov's Test «Your Orderliness»), and perfectionism (the P. Hewitt's and G. Flett's Technique «Multidimensional Perfectionism Scale» in I. Gracheva's adaptation).

The actualization component indicators. The actualization component is represented by the academic motivation indicators (T. Ilyina's Technique «Motivation of Studying in the University»), and the educational and professional activities motivation, (K. Zamfir's Technique for Defining of Professional Activity Motivation in A. A. Rean's modification).

The realization component indicators. The realization component is performed by the control localization indicators (SLC Test - subjective localization of control, S. Pantyleev's and V. Stolin's modification of the
J. Rotter's scale), achievement motivation (Technique of Achieving the Goal and Success Motivation Studying and the T. Ehlers' Technique of Failures Avoiding Motivation Studying, and value orientations (M. Rokich's Technique «Value Orientations»).

The empirical research sample contains 235 Ukrainian psychology students of the I-IV years of study. Among them are 45 young men $(19,15 \%)$ and 190 women $(80,85 \%)$ 16-22 years old.

The organisation of empirical research within the practically-oriented education on the researching bases was provided during classes or after them by the psychologists-researchers. Participants were motivated by the opportunity of getting individual cards with their research results, group consultation, and individual consultations (if it was necessary), devoted to the discussion of the research results. Taking into the account confidentiality of the results, the research data were also used by students in their individual works for training in statistical data processing. The research results were presented at the University conferences, the audience of which was the students-participants of the research.

Quantitative data processing was carried out by the means of the average values defining, percentage ratios, and correlation analysis with the following factor analysis for the system-forming factor defining, which resulted in the following exposing of psychology students' motivational sphere peculiarities.

In order to study the peculiarities of psychology students' motivational sphere orientation component, the average hierarchy in psychology students' emotional orientations' preferences was constructed (Table 1).

The Average Hierarchy in Psychology Students' Emotional Orientations' Preferences

Table 1

\begin{tabular}{|c|l|c|}
\hline No. & \multicolumn{1}{|c|}{ Emotional orientations } & Average value (points) \\
\hline 1. & Communicative & 5.95 \\
\hline 2. & Hedonistic & 5.40 \\
\hline 3. & Altruistic & 5.39 \\
\hline 4. & Praxisic & 5.15 \\
\hline 5. & Glory & 4.82 \\
\hline 6. & Aesthetic & 4.03 \\
\hline 7. & Acquisitive & 3.96 \\
\hline 8. & Romantic & 3.82 \\
\hline 9. & Gnostic & 3.66 \\
\hline 10. & Pugnatic & 2.81 \\
\hline
\end{tabular}

Table 2

The Research Results of Psychology Students' Motivational Sphere's Mobilization Component

\begin{tabular}{|c|l|c|c|c|c|}
\hline \multirow{2}{*}{ No. Indicators } & \multicolumn{2}{|c|}{$\begin{array}{c}\text { Average value } \\
\text { (points) }\end{array}$} & \multicolumn{3}{|c|}{$\begin{array}{c}\text { Levels representation } \\
\text { (\% of students) }\end{array}$} \\
\cline { 4 - 5 } & & 29.17 & 14.04 & 60.43 & 25.53 \\
\hline 1. & Adaptability & 46.49 & 2.13 & 54.47 & 43.40 \\
\hline 2. & Personality anxiety & 44.76 & 53.62 & 39.57 & 6.81 \\
\hline 3. & Orderliness & 174.89 & 30.21 & 50.21 & 19.58 \\
\hline 4. & General perfectionism & 66.11 & 22.55 & 33.62 & 43.83 \\
\hline 5. & Self-oriented perfectionism & 53.55 & 48.51 & 37.45 & 14.04 \\
\hline 6. & Socially oriented perfectionism & 55.23 & 41.70 & 39.57 & 18.73 \\
\hline 7. & Socially pre-scripted perfectionism & & & & Mean \\
\hline
\end{tabular}


Table 4

The Research Results of Control Localization and Achievement Motivation in Psychology Students

\begin{tabular}{|c|l|c|c|c|c|}
\hline \multirow{2}{*}{ No. } & \multicolumn{1}{|c|}{ Indicators } & \multirow{2}{*}{$\begin{array}{c}\text { Average value } \\
\text { (points) }\end{array}$} & \multicolumn{3}{|c|}{$\begin{array}{c}\text { Levels representation } \\
\text { (\%) of students) }\end{array}$} \\
\cline { 4 - 6 } & & 16.77 & Low & Mean & High \\
\hline 1. & Control localization internality & 16.53 & 31.49 & 62.98 \\
\hline 2. & Success achievement motivation & 16.02 & 8.51 & 47.23 & 44.26 \\
\hline 3. & Failure avoidance motivation & 13.66 & 25.11 & 48.51 & 26.38 \\
\hline
\end{tabular}

Value Orientations Average Hierarchy in Psychology Students

\begin{tabular}{|c|l|c|l|c|}
\hline No. & \multicolumn{1}{|c|}{ Terminal values } & $\begin{array}{c}\text { Average } \\
\text { (points) }\end{array}$ & \multicolumn{1}{c|}{$\begin{array}{c}\text { Instrumental values } \\
\text { (points) }\end{array}$} & 10.33 \\
\hline 1. & Health & 10.52 & Cheerfulness & 9.82 \\
\hline 2. & Love & 10.19 & Parenting & 9.74 \\
\hline 3. & Active life & 9.81 & ndependence & 9,36 \\
\hline 4. & Good and true friends & 9.52 & Honesty & 9,03 \\
\hline 5. & Interesting work & 9.27 & Education & 9,01 \\
\hline 6. & Self-confidence & 9,07 & Sensitivity & 8,66 \\
\hline 7. & Life wisdom & 8.96 & Width of views & 8.59 \\
\hline 8. & Happy family life & 8.71 & Responsibility & 8.33 \\
\hline 9. & Materially secure life & 8.66 & Accuracy & 8.21 \\
\hline 10. & Development & 8.40 & Firm will & 8.20 \\
\hline 11. & Freedom & 8.28 & Rationalism & 8.16 \\
\hline 12. & The beauty of nature and art & 8.21 & Courage in defending own thoughts and views & 8.09 \\
\hline 13. & Entertainment & 7.67 & Discipline & 8.01 \\
\hline 14. & Productive life & 7.60 & Self-control & 7.92 \\
\hline 15. & Public recognition & 7.56 & High demands & 7.55 \\
\hline 16. & Cognition & 7.34 & Tolerance & 7.16 \\
\hline 17. & Creativity & 7.24 & Effectiveness in business & 6.83 \\
\hline 18. & The happiness of others & 6.80 & Non-consistency to the own and others' imperfection & \\
\hline
\end{tabular}

Table 6

The Results of Psychology Students' Motivational Sphere Indicators Correlation Analysis $(p=235)$

\begin{tabular}{|c|c|c|c|c|c|c|c|c|c|c|}
\hline & 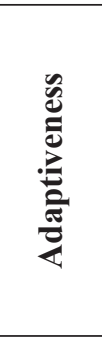 & 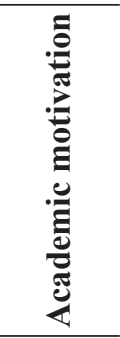 & 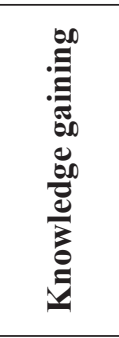 & 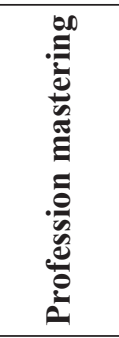 & 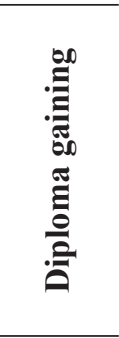 & 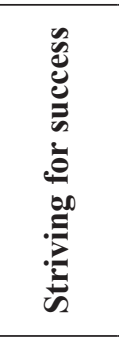 & & 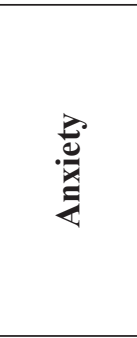 & 递 & 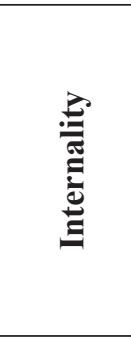 \\
\hline Perfectionism & $0.12 *$ & $0.17 * *$ & $0.15^{*}$ & 0.03 & $0.14 *$ & $0.41 * *$ & -0.03 & $0.13 *$ & $0.18 *$ & 0.09 \\
\hline Adaptiveness & - & $0.22 * *$ & $0.20 * *$ & $0.12 *$ & 0.09 & $0.32 * *$ & -0.08 & $-0.47 * *$ & $0.43 * *$ & $0.26 * *$ \\
\hline Academic motivation & - & - & $0.69 * *$ & $0.62 * *$ & $0.54 * *$ & $0.23 * *$ & $0.13^{*}$ & $-0.12^{*}$ & $0.27 * *$ & $0.31 * *$ \\
\hline Knowledge gaining & - & - & - & $0.22 * *$ & 0.08 & $0.18 * *$ & $0.20 * *$ & -0.11 & $0.25 * *$ & $0.26 * *$ \\
\hline Profession mastering & - & - & - & - & 0.03 & $0.18^{* *}$ & -0.01 & $-0.16^{* *}$ & 0.09 & $0.16^{* *}$ \\
\hline Diploma gaining & - & - & - & - & - & $0.13^{*}$ & 0.02 & 0.05 & $0.14 *$ & $0.13^{*}$ \\
\hline Striving for success & - & - & - & - & - & - & -0.04 & $-0.14^{*}$ & $0.39 * *$ & $0.23^{*}$ \\
\hline Fear of failure & - & - & - & - & - & - & - & $0.20 * *$ & $0.20 * *$ & 0.03 \\
\hline Anxiety & - & - & - & - & - & - & - & - & $-0.18 * *$ & $-0.29 * *$ \\
\hline Orderliness & - & - & - & - & - & - & - & - & - & $0.32 * *$ \\
\hline
\end{tabular}

Примітка: * $-\mathrm{p} \leq 0,05 ; * *-\mathrm{p} \leq 0,01$ 
The orientation component of personality's motivational sphere study is complicated by the fact that it is formed mostly of innate, unrealized phenomena, or displaced by the personality's psyche in the process of life to the sphere of the unconscious. For the psyche's unconscious sphere study in modern classical psychology, in fact, there are no psychodiagnostic techniques, which would allow applying statistical data processing methods for classical scientific conclusions' substantiation. Therefore, in our study, the personality's motivational sphere orientation component's peculiarities were studied using the technique for the emotional orientation structure determining and the average hierarchy in psychology students' particular orientation's preferences was built (see Table 1).

The «pugnatic» emotions, associated with pleasure from the struggle, are in the last place. It may indicate the psychology students' dislikes and unwillingness to compete with their classmates in the process of profession mastering. A rating system of knowledge assessment, introduced in institutions of higher education, provokes students to compete with each other. Dislikes of hard competition may be one of the factors reducing students' academic motivation. The high rank of hedonistic emotions also does not promote motivation to study in a credit-module system. Hedonistically oriented persons are trying to avoid places and situations where they feel uncomfortable - and our respondents feel uncomfortable in struggle conditions, thrust on them in one or another way in the situation, for instance, of a students' knowledge assessing rating system. The «acquisitive» emotions associated with the love of accumulation are at the end of the emotional preferences list, and in a credit-module system, it is desirable to «like» the scores accumulation - the more points you gain, the more successful student you are considered to be. For psychology students, the «acquisitive» orientation is not typical; our observations also confirm that they are not inclined to score points for their educational achievements from a large number of study subjects. «Gnostic» emotions are at the penultimate point, which does not correspond to the student's of a higher school social role and is not consistent with the professiogram and psychogram of a specialist in psychology, great importance in which is given to the psychologist's orientation on personality's inner world cognition, which is more complex phenomenon than the process of natural cognition.

The correlation analysis, carried out for a profound study of the emotional experiences' correlations in the structure of emotional orientation, shows, that most of the correlation coefficients between the ranks of different emotions are either insignificant or small in strength. Quite interesting were the following strong enough four correlations, statistically significant at the level $p \leq 0.01$ : an inverse correlation was found between the rank of «hedonistic» emotions and the rank of «gnostic» emotions $(\mathrm{r}=-0.30)$; The correlation between the rank of «communicative» emotions and the rank of «romantic» emotions $(r=0.29)$; the correlation between the rank of «communicative» emotions and the rank of the «glory» emotions $(\mathrm{r}=-0.27)$; between the rank of «aesthetic» emotions and the rank of «praxic» emotions is similar to the previous correlation $(r=-0.27)$.

Correlation analysis showed the absence of correlations between the most of emotional orientation types that testifies on the high prognostic value of this methodic and gives an opportunity to apply the method of related psychological parameters' nonlinear correlation analysis for the construction of personality typology by the indicators of emotional orientation. Such personality typology construction may become a heuristic research-training task for the future psychologists' professionalization owing to the development of their personality's motivational sphere actualization component.

The adaptability, personality anxiety, orderliness, and perfectionism as indicators of the personality's motivational sphere's mobilization component's study results' analysis revealed the following peculiarities among students-psychologists (see Table 2).

The average value of the subjects' adaptability level corresponds to a moderate level of adaptability. The vast majority of students have a mean level of adaptability. As O. Pryshchepa [5] notes, adaptation processes need to be connected not so much with the phenomenon of adaptation, but with the process of development, during which there is a life position rethinking, a values re-estimation, choosing of an adequate behaviour and self-improvement strategy take place. The problem of adaptation is particularly important concerning psychology students because adaptability is a personality maturity indication, and personality maturity the most necessary quality for a plasticising psychologist.

The average value of the level of subjects' personality anxiety corresponds to the limit between the mean and high level of personality anxiety, which begins with 46 points. Personality anxiety, although it has a physiologically innate basis (properties of the nervous system), develops as a result of the social factors' influence [6], therefore the high levels of personality anxiety predominance indicates that future psychologists are in an unfavourable for their personality social conditions.

The average level of orderliness in the subjects corresponds to the low level. A large percentage of unorganized students in a sample of psychologists cause the anxiety since the psychologist's professional activity requires an extremely high level of discipline and organization.

The average value of general perfectionism corresponds to the mean level. The average value of the selforiented perfectionism, socially oriented perfectionism, socially pre-scripted perfectionism in the subjects is within the mean level.

The average profile of perfectionism in the subjects is the following: «self-oriented perfectionism» > «socially oriented perfectionism» $>$ «socially pre-scripted perfectionism». It means that the subjects are more likely to make demands on themselves, and not on the others, and, in turn, do not consider that they are under the exaggerated demands. The low level of perfectionism leads to a superficial, irresponsible attitude to learning, and high also performs a negative function: perfectionists often do not fit into the required tasks' fulfilment timing. 
The psychology students' motivational sphere's actualization component's peculiarities were studied, as mentioned above, by the indicators of academic motivation and motivation of educational and professional activities (see Table 3).

Revealed information about the academic motivation peculiarities is the following: the general level of academic motivation, the level of knowledge gaining motive's display, the profession mastering motive, the diploma getting motive. The average value of general academic motivation in the subjects corresponds to the mean level. The average value of knowledge gaining motive and the diploma getting motive in the subjects are also within the mean level. The average value of the profession mastering motive's display in the subjects is within the middle level.

As we see from the mentioned above average values of the indicators, the students' motivation is represented by the domination of the leading motive of studying at the institution of higher education - the getting a diploma. In the second place is the profession mastering motive, on the last - the knowledge gaining motive. This tendency is rather negative, it testifies to the strengthening of the formal aspect of learning through the content. N. Alyokhina [7], who obtained similar data in her studies, rightly points out that in modern socio-political conditions not knowledge and education become a value, but an education acquisition document.

The following data were obtained concerning the levels of internal motivation, external positive and external negative motivation. The average value of internal motivation in the subjects corresponds to the high level. The average value of external positive motivation in the subjects corresponds to the mean level. The average external negative motivation in the subjects corresponds to the low level.

Concerning the motivation of professional activity, it is considered to be optimal when the indicator of external negative motivation does not exceed the indicator of external positive and internal motivation, which is observed in almost all of our subjects (the predominance of educational and professional activity internal motivation of students-psychologists, external positive motivation is in the second place, external negative in the last). Such results indicate that motivating future psychologists to study by the encouragement or punishment is ineffective.

The personality's motivational sphere's realization component was studied basing on the indicators of control localization, achievement motivation (see Table 4), and value orientations (see Table 5), which resulted in the following psychology students' motivational sphere's peculiarities.

The average value of the control locus internality corresponds to the internal control locus. Attention is paid to the prevalence of internality compared with externality in future psychologists. The internal locus of control is usually considered by the researchers as positive [8], but there are certain restrictions. People with a significantly internal control locus are excessively inclined to a selfreflection, as well as self-accusation.

The average value of the motivation for success achievement in the subjects corresponds to the transi- tion limit from the mean to the high level. The average value of failure avoidance motivation in the subjects corresponds to the mean level.

The value orientations study results' analysis gave an opportunity to construct an average hierarchy in giving preference to a certain value by psychology students (see Table 5).

As we see, in the first place there are such terminal values as «love» (I rank), «health» (II rank), «active life» (III rank). Similar data were obtained by N. Antonova [9] on a sample of III-V years of study students of psychological specialities, and there were no significant differences in the value orientations system between students with a high level of professional motivation and students with its low level. In the study of N. Antonova [9], as in ours, it was discovered that in psychology students the value "active life», «health», «love» are in the upper positions, while aesthetic values are close to the end of the list.

For the psychology students similar data were obtained in the studies of M. Yatchuk [10] (in particular, it was found that the first positions in the value orientations system occupy the values of «love» and «happy family life»). M.Yatchuk [10] compared the value orientations of cadets of higher educational institutions of the Ministry of Internal Affairs of Ukraine and revealed significant differences in the system of value orientations and its dynamics among psychology students and cadets. Psychology students showed an increase in the personal life and interpersonal communication values during their studies, while for cadets such values are not significant and become even less significant during the period of their education.

It looks a little weird for psychology students to put «creativity», «happiness of others», and «cognition» in the last places. By the way, similar data were obtained in the research of I. Shlimakova and O. Mohylevets [11] concerning to psychologists of other universities, where future psychologists do not care about creativity, happiness and cognition. According to these researchers, the prominent place among psychology students takes the value of «interesting work». We got almost the same data: the rank of value «interesting work» is in the fifth place. The coincidence of many independent studies' results conducted in various institutions of higher education indicates the existence of a specific system of value orientations that is common to an ordinary psychology student.

As we see in the hierarchy of instrumental values (see Table 5), in the first place there are instrumental values of «cheerfulness» (I rank), «education» (II rank), «independence» (III rank). The desire for independence often indicates that there is an awareness of dependency, which is typical for adolescents rather than adults.

«Effectiveness in business» and "tolerance» in the last places somehow coincides with the ethical requirements for the psychologist's professional activity concerning conscientiousness and tolerance. This situation is to some extent is compensated by the fact that the value of «non-consistency to the own and others' imperfection» is also in the last place. 
Let's discuss the correlation coefficients of the eleven indicators of personality's motivational sphere (adaptiveness, personality anxiety, orderliness, perfectionism, academic motivation, the motivation of knowledge gaining, profession mastering, diploma gaining, internality, striving for success, and fear of failure (see Table 6).

Rather interesting and illustrative are following correlations:

- between the level of adaptiveness and the level of personality anxiety $(\mathrm{r}=-0,47)$;

- between the level of adaptiveness and the level of orderliness $(r=0,43)$

- between the level of general perfectionism and a will to succeed $(r=0,41)$;

- between the level of orderliness and a will to succeed $(r=0,39)$;

- between the level of adaptiveness and a will to succeed $(r=0,32)$;

- between the level of internality control localization and a level of orderliness $(r=0,32)$;

- between the level of internality control localization and a general level of academic motivation $(\mathrm{r}=0,31)$;

- between the level of internality control localization and a level of personality anxiety $(r=-0,29)$;

- between a general level of academic motivation and a level of orderliness $(\mathrm{r}=0,27)$.

High values of correlation coefficients between a general level of academic motivation on the one hand, and the levels of knowledge gaining, profession mastering and getting a diploma motivations on the other, are obvious because general level of academic motivation consists of the sum of these three components, and, consequently, the larger is an element, the larger is a sum. But we can take some useful information from these numbers - the largest contribution to the general academic motivation makes a knowledge gaining motivation $(\mathrm{r}=0,69)$, and the least a diploma getting motivation $(\mathrm{r}=0,54)$.

As it was explained above, other correlations, albeit most of them are significant, does not testify to the connection of these parameters. We should pay attention to the absence of a significant correlation of separate personality's motivational sphere indicators with the other studied parameters. Particularly, a failure avoidance motivation (fear of failures) has a very weak correlation on the level of $r=0,20$ with $p \leq 0,01$ only with the motivation of knowledge gaining, orderliness and anxiety. It provides a basis for making an assumption that fear of failure appears in the conditions of educational environment, influences on the personality's orderliness and anxiety. The revealed fact can become a basis for the fear of failure phenomenon research problem statement and further fundamental analysis within the nonlinear model of personality's motivational sphere.

Therefore, the empirical research results' analysis allows distinguishing the following peculiarities of psychology students' motivational sphere. Emotional orientation as an indicator of the subjects' motivational sphere's orientation component is characterized by the fact that «communicative», «altruistic», «hedonistic» emotions are in the first place; «pugnic», «aesthetic», «Gnostic» are the last ones. This testifies that for students-psychologists the greatest emotional satisfaction brings communication, assistance to people and comfort, and the least - struggle, beauty and cognition.

The peculiarity of the psychology students' motivational sphere's mobilization component is the mean level of adaptability, as well as the mean level of general perfectionism and its separate components. The level of personality anxiety is fixed in future psychologists at a level above the mean. Most psychologists have a low level of orderliness, which is a system-forming factor of this component according to our factor loadings' calculations.

In the psychology students' motivational sphere's actualization component we revealed the predominance of internal motivation for educational and professional activity; in the second place is an external positive motivation, the last is external negative. The leading motive for studying at a higher education institution for future psychologists is to get a diploma; in the second place there is a profession mastering motive, the last is knowledge gaining motive, which is a system-forming factor of this component according to our factor loadings' calculations.

The peculiarities of the psychology students' motivational sphere's realization component are following. The vast majority of future psychologists are inclined to assume responsibility for everything that happens to themselves, not to other people or to independent circumstances (that is, they have an internal control locus). The motivation of success achieving, which is a system-forming factor of this component, and the failures avoiding motivation are at a mean level. According to the average group rank of values, future psychologists prefer, in the first place there are such terminal values as «love», «health», «active life», at the last - «cognition», «creativity», «happiness of others». The instrumental values psychology students are guided in their lives are «cheerfulness», «education», «independence», while the last places are «tolerance», «effectiveness in business», «nonconsistency to the own and others' imperfection».

The revealed psychology students' motivational sphere's peculiarities can prompt to find new empirical indicators of the personality's motivational sphere. The studied peculiarities enable in the perspective to construct an integrated motivational profile of the psychology students' personality, and according to individual indicators of the personality's motivational sphere of each student, to build his individual motivational profile, which will become the basis for scientifically grounded management of a gifted personality's development in the conditions of educational environment. A deep analysis of the motivational sphere's peculiarities and the correlations between its indicators can determine the problem statement of the personality's motivational processes' synergy identifying.

\section{Використані літературні джерела}

1. Подшивайлова Л.І. Аксіоматичний підхід як засіб подолання понятійної невизначеності у психології / Л.І. Подшивайлова // Науковий вісник Миколаївського державного 
університету імені В.О. Сухомлинського : збірник наукових праць / за ред. С.Д. Максименка, Н.О. Свдокимової. Т. 2. Вип. 5. Миколаїв : МДУ імені В.О. Сухомлинського, 2010. С. 229-233. Серія «Психологічні науки».

2. Подиивайлов Ф.М. Теоретико-методологічні засади визначення поняття мотиваційної сфери особистості / Ф.М. Подшивайлов // Освіта та розвиток обдарованої особистості. 2015. № 10 (41). С. 19-23.

3. Подшивайлов Ф.М. Теоретичне обгрунтування моделі мотиваційної сфери особистості / Ф.М. Подшивайлов // Актуальні проблеми психології: збірник наукових праць Інституту психології імені Г.С. Костюка НАПН України. Київ : Фенікс, 2017. Т. ХІІ. Психологія творчості. Вип. 23. С. 248-263.

5. Прищепа О.А. Адаптація особистості як проблема психологічної науки / О.А. Прищепа // Проблеми загальної та педагогічної психології : збірник наукових праць Інституту психології імені Г.С. Костюка НАПН України / за ред. С.Д. Максименка. Т. ХІІ. Ч. 6. Київ, 2010. С. 308-316.

6. Современный психологический словарь / сост. и общ. ред. Б.Г. Мещеряков, В.П. Зинченко. Москва; СанктПетербург : ПРАЙМ-ЕВРОЗНАК, 2007. 290 с.

7. Альохіна Н.В. Дослідження мотивації навчання у вищому навчальному закладі / Н. В. Альохіна // Проблеми загальної та педагогічної психології : збірник наукових праць Інституту психології ім. Г.С. Костюка НАПН України / за ред. С.Д. Максименка. Т. ХІІ. Ч. 6. Київ, 2010. С. 7-14.

8. Подоляк Л.Г. Психологія вищої школи : практикум / Л.Г. Подоляк, В.І. Юрченко. Київ : Каравела, 2008. 336 с.

9. Антонова Н.О. Особливості професійної мотивації студентів психологічного факультету / Н.О. Антонова // Актуальні проблеми психології : збірник наукових праць Інституту психології ім. Г.С. Костюка НАПН України / за ред. В.О. Моляко. Т. 12. Вип. 10. Ч. ІІ. Житомир : Вид-во ЖДУ ім. І. Франка, 2010. С. 22-33.

10. Ятчук М.С. Порівняння динаміки змін особистості курсантів і студентів вищих навчальних закладів МВС України в процесі навчання / М.С. Ятчук // Актуальні проблеми психології : збірник наукових праць Інституту психології ім. Г.С. Костюка АПН України / за ред. В.О. Моляко. Т. 12. Вип. 10. Ч. ІІ. Житомир : Вид-во ЖДУ ім. І. Франка, 2010. C. $447-455$.

11. Шлімакова I.I. Динаміка змін професійно-значимих ціннісних орієнтацій практичних психологів / I.I. Шлімакова, О. П. Могилевець // Практична психологія та соціальна робота. 2013. № 9. С. 9-13.

\section{References}

1. Podshyvailova, L.I. (2010). Aksiomatychnyi pidkhid yak zasib podolannia poniatiinoi nevyznachenosti u psykholohii [Axiomatic approach as a means of conceptual uncertainty overcoming in psychology]. Scientific Journal of V. A. Sukhomlynsky Mykolayiv State University: Collected Works. 2(5), P. 229-233.

2. Podshyvailov, F.M. (2015). Teoretyko-metodolohichni zasady vyznachennia poniattia motyvatsiinoi sfery osobystosti [Theoretical-methodological grounds of the personality's motivational sphere notion defining]. Education and development of a gifted personality. 10(41), P. 19-23.
3. Podshyvailov, F.M. (2017). Teoretychne obgruntuvannia modeli motyvatsiinoi sfery osobystosti [Theoretical justification of the personality's motivational sphere model]. Actual problems of psychology: Scientific works collection of the H. S. Kostiuk Institute of psychology of NAES of Ukraine. Psychology of creativity, 12(23). P. 248-263.

4. Podshyvailov, F.M. (2016) Model motyvatsiinoi sfery osobystosti [Model of Motivational sphere of personality] Education and development of a gifted personality. 11 (54), P. 39-43.

5. Pryshchepa, O.A. (2010). Adaptatsiia osobystosti iak problema psykholohichnoi nauky [Adaptation of personality as a psychological science's problem]. The problems of general and educational psychology: Scientific works collection of the H. S. Kostiuk Institute of psychology of NAES of Ukraine, 12(6), P. 308-316.

6. Meshcheriakov, B.G., Zinchenko, V.P. (Eds.) (2007). Sovremennyi Psikholohicheskii slovar [Modern psychological dictionary], St. Petersburg: PRIME-EVROZNAK.

7. Alyokhina, N.V. (2010). Doslidzhennia motyvatsii navchannia u vyshchomu navchalnomu zakladi [The research of academic motivation in higher educational establishment]. The problems of general and educational psychology: Scientific works collection of the H. S. Kostiuk Institute of psychology of NAES of Ukraine. 12(6), P. 7-14.

8. Podoliak, L.G. \& Yurchenko, V.I. (2008). Psykholohiia vyshchoi shkoly: praktykum [Psychology of higher school: tutorial]. Kyiv: Karavela.

9. Antonova, N.O. (2010). Osoblyvosti profesiinoi motyvatsii studentiv psykholohichnoho fakultetu [The peculiarities of the psychological faculty students' professional motivation]. Actual problems of psychology: Scientific works collection of the H. S. Kostiuk Institute of psychology of NAES of Ukraine. Psychology of creativity. 12(10/2), P. 22-33.

10. Yatchuk, M.S. (2010). Porivniannia dynamiky zmin osobystosti kursantiv i studentiv vyshchykh navchalnykh zakladiv MVS Ukrainy v protsessi navchannia [The dynamics of MIA cadets and students of higher educational establishments personality changes' comparison in the process of study]. Actual problems of psychology: Scientific works collection of the H. S. Kostiuk Institute of psychology of NAES of Ukraine. Psychology of creativity. 12(10/2), P. 447-455.

11. Shlimakova, I.I. \& Mohylevets, O.P. (2013). Dynamika zmin profesiino-znachymykh tsinnisnykh oriientatsii praktychnykh psykholohiv [The dynamics of practical psychologists' professionally-significant value orientations changing]. Practical psychology and social work. 9, P. 9-13.

Подшивайлов Ф.М., Подшивайлова Л.І. Мотиваційна сфера сучасних студентів-психологів: теоретико-емпіричний аналіз.

Анотація.

Стаття присвячена аналізу результатів емпіричного дослідження особливостей мотиваційной сфери студентів-психологів. В основу дослідження покладено теоретично обтрунтовану модель мотиваційної сфери особистості, в якій виділено чотири складові: орієнтаціийну, мобілізаційну, актуалізаційну та реалізащіийу. Орієнтаційна складова представлена показником емоційної спрямованості; 
мобілізаиійна - показниками адаптивності, особистісної тривожності, організованості, перфекиіонізму; актуалізачійна - показниками навчальної мотивації та мотивації навчально-професійної діяльності; реалізачійна - показниками локалізачії контролю, мотивачії досягнення, ичіннісних орієнтаиій.

Емоиійна спрямованість студентів-психологів характеризується тим, щзо на перших місиях знаходяться "комунікативні», "альтруїстичні», "гедоністичні» емоції, на останніх - «пугнічні», «естетичні», «гностичні».

У студентів-психологів виявлено середній рівень адаптивності; вище середнього рівень особистісної тривожності; низький рівень організованості; середній рівень як загального перфекціонізму, так і окремих його складових. У майбутніх психологів домінує внутрішня мотивація навчально-професійної діяльності, на другому місиі знаходиться зовнішня позитивна мотивачія, на останньому - зовнішня негативна; провідним мотивом навчання є отримання диплома, на другому місиі знаходиться мотив оволодіння професією, на останньому - отримання знань.

Більшість студентів-психологів мають інтернальний локус контролю; мотивація досягнення успіху та мотивація уникнення невдач знаходяться на середньому рівні, при изьому середнє значення мотиваціі досягнення успіху трохи вище (на 2,36 бала) за середнє значення мотивації уникнення невдач. За середньогруповим рангом ияіностей, яким майбутні психологи надають перевагу, на перших місиях стоять такі термінальні иінності, як «любов», «здоров'я», «активне діяльне жсття», на останніх - «пізнання», «творчість», «щастя інших». Інструментальними цінностями, якими студенти-психологи керуються у житті, є «життерадісність», «вихованість», «незалежність», причому на останніх місиях знаходиться «терпимість», «ефективність у справах», «непримиримість до недоліків у себе та інших людях».

Ключові слова: мотиваційна сфера особистості; студенти-психологи; емпіричне дослідження; емоційна спрямованість; адаптивність; особистісна тривожність; організованість; перфекиіонізм; навчальна мотивація; мотивачія навчально-професійної діяльності; локалізаиія контролю; мотивачія досягнення (мотивація досягнення успіху, мотиваџія уникнення невдач); иіннісні орієнтації.

Подшивайлов Ф.М., Подшивайлова Л.И. Мотивационная сфера современных студентов-психологов: теоретико-эмпирический анализ.

Аннотация.

В статье представлень особенности мотивациионной сферы студентов-психологов, выявленные в результате эмпирического исследования, проведенного на основе теоретически обоснованной модели мотивачионной сферы личности. Эмпирическими показателями для исследования были: эмоциональная направленность; адаптивность, личностная тревожность, организованность, перфекиионизм; учебная мотивачия, мотивачия учебно-профессиональной деятельности (икаль «получение знаний», «овладение профессией», «получение диплома»); локализацуия контроля, мотивация достижения (мотивация стремления к успеху, мотивация избегания неудач), ценностные ориентациии.

Ключевые слова: мотивачионная сфера личности; студенты-психологи; эмпирическое исследование; эмоичиональная направленность; адаптивность; личностная тревожность; организованность; перфекционизм; учебная мотивация; локализация контроля; мотивация достижения (стремление к успеху, избегание неудач); изенностные ориентациии. 